\title{
Women's Prisons:
}

\section{An Equal Protection Evaluation}

Prisons in the United States are segregated on the basis of sex. ${ }^{1}$ Despite the explicit gender basis of institutional assignments and the recognition that prison inmates retain their equal protection rights, no court has subjected the segregation of male and female prisoners to the level of review mandated by the Constitution. Instead of examining the purposes behind the decision to segregate the sexes and the relationship of absolute separation to the attainment of those purposes, courts have focused on the provision of specific services. They have employed an extremely weak standard of review, which requires only that segregated prisons provide "parity of treatment" to male and female prisoners. ${ }^{2}$

This Note argues that the segregation of women in prison merits at least the rigorous intermediate scrutiny mandated by Mississippi University for Women v. Hogan, ${ }^{3}$ and that it cannot meet that level of review. It proposes a gender-neutral system of inmate assignment to remedy unconstitutional segregation. As will be shown, concern for the safety of women inmates is the only legitimate objection to a desegregation remedy. The Constitution requires, however, that the protection of the small number of women whose safety might be threatened in integrated prisons be secured through less restrictive alternatives than systematic segregation by sex.

\section{The System of Segregation}

At the federal, state, and county levels, women are incarcerated in facilities that separate them from men. Typically, state prisons effect this separation through institutions designed exclusively for women. County jails, on the other hand, most often segregate women in a unit within the confines of a larger facility. Such units function autonomously, with little or no mixing of the male and female populations. ${ }^{4}$ In segregated prisons and

1. This Note focuses on sentenced, adult women in prison. The conditions of juveniles and pretrial detainees present other problems and concerns which, for the most part, are outside the scope of this Note.

2. See, e.g., Canterino v. Wilson, 546 F. Supp. 174 (W.D. Ky. 1982) (Canterino I), motion granting supp. relief, 562 F. Supp. 106 (W.D. Ky. 1983) (Canterino II); Batton v. North Carolina, 501 F. Supp. 1173 (E.D.N.C. 1980); Bukhari v. Hutto, 487 F. Supp. 1162 (E.D. Va. 1980); Glover v. Johnson, 478 F. Supp. 1075 (E.D. Mich. 1979).

3. 458 U.S. 718 (1982).

4. While the analysis in this Note applies primarily to separate, all-female institutions, most of the discussion also applies to women's units which are operated autonomously within a prison for men. Several challenges have been made to unequal treatment between men's and women's units. See, e.g., McMurry v. Phelps, 533 F. Supp. 742, 767-68 (W.D. La. 1982) (constitutional violations found in county jail that prohibited women inmates from serving as trustees or enjoying less restrictive 
in women's units in men's prisons, women have access to fewer rehabilitative programs, and those few available are inferior to those offered men; they also have fewer and less specialized services and facilities. ${ }^{5}$

The issue of segregation is complicated by the fact that women constitute a very small proportion of the nation's prison population. ${ }^{6}$ Because there are so few incarcerated women, once the decision to segregate has been made, most states can maintain only one or two facilities for adult women, ${ }^{7}$ and these prisons are considerably smaller than men's institutions. ${ }^{8}$ While men are assigned to prisons based on a variety of factors,

confinement at prison "farm"); Mitchell v. Untreiner, 421 F. Supp. 886, 895 (N.D. Fla. 1976) (same).

5. See R. Glick \& V. Neto, National Study of Women's Correctional Programs xivxvii (1977); U.S. Nat'l Advisory Comm'N ON Criminal Justice Standards and Goals, CoRRECTIONS 379 (1973) (Commentary to Standard 11.6); Fabian, Toward the Best Interests of Women Prisoners: Is the System Working?, 6 NEw ENG. J. PRIsON L. 1, 17-24 (1979); Note, The Sexual Segregation of American Prisons, 82 YALE L.J. 1229, 1236-37, 1239, 1241-43 (1973).

6. Many fewer women become involved with the criminal justice system at all stages of the process, but particularly at the incarceration stage. Chesney-Lind, Chivalry Reexamined: Women and the Criminal Justice System, in Women, Crime and the Criminal Justice System 197 (L. Bowker ed. 1978). In 1982, women comprised $4.18 \%$ of the nation's incarcerated population. BUREAU of the Census, U.S. Dep't of Commerce, Statistical Abstract of the United States 1984, at 194 (104th ed. 1983). Even this small figure reflects recent increases in criminality among women, particularly for property-related crimes. C. FeINMAN, WOMEN IN THE CRIMINAL JUSTICE SYSTEM 14-15 (1980); Chesney-Lind, supra, at 197-98.

Several theories attribute the size differential between the male and female offender populations to societal discrimination. For example, a "chivalry" theory holds that while women commit crimes, they benefit from the male-dominated criminal justice sytem's leniency or chivalry toward them at each stage in the criminal process from arrest to incarceration. See, e.g., C. FeInMan, supra, at 22-25; Fabian, supra note 5, at 14-15; Nagel \& Hagan, Gender and Crime: Offense Patterns and Criminal Court Sanctions, in 4 Crime and Justice: An AnNual Review of Research 91, 112-15 (M. Tonry \& N. Morris eds. 1983). The plausibility of this theory was recognized in Craig v. Boren, 429 U.S. 190, 202 n.14 (1976). According to another theory, women are conditioned from birth to be more passive and concerned for the well-being of others than are men. This indoctrination is said to account for the smaller number of women criminals and the less violent nature of their crimes. See infra note 36. As a corollary to this theory, the relatively greater percentage increase in female crime is attributed to the breakdown of these traditional roles and values brought about by the women's liberation movement. See C. Feinman, supra, at 17-22; Parisi, Exploring Female Crime Patterns: Problems and Prospects, in Judge, LAwYer, Victim, Thief: Women, Gender Roles, and Criminal JusTICE 111, 123-25 (N. Rafter \& E. Stanko eds. 1982).

7. Fabian, supra note 5, at 17; American Correctional Ass'n, Juvenile \& Adult CorreCtional Departments, InStitutions \& Paroling Authorities xxxiv-v (1984) [hereinafter cited as ACA 1984 DiRECTORY]. The greater number of male inmates justifies the existence of several state penal institutions for men, which may be scattered around a state. While the location of prisons and their accessibility to family and friends is a problem for men as well as women, the greater number of prisons for men increases the available options.

Some states do not have facilities to house their women offenders; they contract with neighboring states. C. FeINMAN, supra note 6, at 27. This practice was invalidated in State $e x$ rel. Olson v. Maxwell, 259 N.W.2d 621 (N.D. 1977) (invalidating North Dakota's präctice of sending women to Minnesota prisons, primarily on due process grounds, since out-of-state transfers affecting protected liberty interest occurred without hearing). In Olim v. Wakinekona, 461 U.S. 238 (1983), the Supreme Court cast doubt upon the due process basis of Olson. In upholding a male inmate's transfer from a prison in Hawaii to one in California, the Court established that an inmate has no justifiable expectation of incarceration in any particular state. However, where men are not routinely housed out of state, there would still be an equal protection claim.

8. Women's prisons typically hold fewer than 250 inmates. C. Feinman, supra note 6 , at 28. 
such as offense-type, prior criminal history, and psychological disorders, ${ }^{9}$ the limited number of women's prisons makes similar, specialized assignments for women impossible within a segregated system.

A segregated institutional pattern is the dominant one, but there are exceptions, particulary in the federal prison system. ${ }^{10}$ These so-called "cocorrectional" prisons are generally limited to low security prisoners, house a relatively small number of inmates, and attempt to limit sexual contact between inmates. ${ }^{11}$ Although they are not housed together, men and women in these prisons participate jointly in all institutional programs and activities. ${ }^{12}$ The limited data available suggests that these experiments

Prison officials often justify their failure to supply women with the range of services offered to men by claiming that it would be economically unfeasible to develop and implement programs for small groups of inmates or individuals. See, e.g., Glover v. Johnson, 478 F. Supp. 1075, 1085 (E.D. Mich. 1979). Because of their higher rate of incarceration, men benefit from institutional economies of scale.

9. For examples of statutes requiring the classification of men based on such factors as age, offense-type, prior criminal history and psychological disorders, see IND. CODE ANN. $\$ 11-10-2-5$ (Burns 1981); GA. CoDE ANN. § 42-5-52(a) (1982).

The lack of security features frequently means that women's prisons are not as secure as comparably classified men's prisons. To compensate, women's prisons make various internal classifications based on perceived security risks or other needs. At Connecticut's prison for women, CCI-Niantic, for example, one "cottage" (living unit) is for honor status women and youthful offenders who are considered minimal security risks. Internal classifications generally cannot accommodate the needs of the inmates with the demands of the institution to the same extent as could a specially designed prison. See infra note 66 (discussion of problems faced by high-security women in prison).

In Molar v. Gates, 98 Cal. App. 3d 1, 159 Cal. Rptr. 239 (1979), a California court applying both state and federal equal protection clauses required county corrections officials to provide minimum security facilities on a nondiscriminatory basis. However, the court indicated that the county was free to discontinue this option for men, rather than integrate or open separate facilities for women. Id. at 253-54. See also McMurry v. Phelps, 533 F. Supp. 742, 767-68 (W.D. La. 1982) (challenging county jail's provision of less restrictive alternatives for qualified men but not women); Bukhari $v$. Hutto, 487 F. Supp. 1162, 1171-72 (E.D. Va. 1980) (challenging the state's failure to provide women with maximum security facilities comparable to those available to men); Mitchell v. Untreiner, $421 \mathrm{~F}$. Supp. 886, 895 (N.D. Fla. 1976) (also challenging jail's provision of less restrictive confinement to men but not to women); Resnik, Should Prisoners Be Classified By Sex?, in Criminal. CorrecTIONS: IDEALS AND REALITIES 109, 111 (J. Doig ed. 1982) (federal women prisoners are not incarcerated in minimally restrictive "camps," despite eligibility of majority).

10. The United States Bureau of Prisons has experimented with co-correctional programs in Fort Worth, Lexington, Pleasanton, and Terminal Island. Bowker, Females in Corrections, in WOMEN, Crime and the Criminal Justice System, supra note 6, at 225, 236. Fort Worth and Lexington remain co-correctional. ACA 1984 DIRECTORY, supra note 7, at 389-97. Massachusetts Correctional Institution at Framingham, formerly a women's prison, became the first state co-correctional facility for adults in 1973. V. Fox, InTRODuction to CoRRECTIONS 168 (2d. ed. 1977); there are also cocorrectional prisons in Kansas, Alaska, and New York. When Prisons Go Coed, NewsweEk, Jan. 11, 1982 , at 66 .

11. Ruback, The Sexually Integrated Prison: A Legal and Policy Evaluation, 3 AM. J. CRIM. L. 301, 317-18 (1975). For example, "[t]he rules at FCI-Fort Worth permit hand-holding but proscribe kissing and putting one's arm around another person." Id. at 318. See also NewSwEEK, supra note 10 , at 66 ("For the most part, pregnancies are infrequent and punishment for misbehavior is swift."); Coed Incarceration, TIME, Sept. 16, 1974, at 84 ("Sexual activity is banned. Anyone caught violating the rule may be transferred back to an orthodox prison.").

12. See V. Fox, supra note 10 , at 169 ; Bowker, supra note 10 , at 236 . This mixing distinguishes them from those state and local facilities where women are incarcerated in an autonomously functioning unit within a larger prison for men. Cf. Mitchell v. Untreiner, 421 F. Supp. 886 (N.D. Fla. 1976) (women's unit in county jail operated under different-and more restrictive-rules). 
have been successful in the terms traditionally used to evaluate correctional programs; ${ }^{13}$ indeed, several national correctional organizations now endorse such co-correctional facilities. ${ }^{14}$

\section{The Equal Protection Clause and Women's Prisons}

\section{A. Modern Equal Protection Doctrine}

Prisoners lose only those constitutional rights fundamentally inconsistent with their status as inmates. ${ }^{15}$ Because incarcerated persons retain the right of equal protection, ${ }^{16}$ sex segregation in prisons must be measured by the norms of the equal protection clause.

Modern equal protection analysis employs three different levels of judicial review: deferential "rational basis" review, ${ }^{17}$ intermediate

13. See V. Fox, Correctional Institutions 218 (1983); Ruback, supra note 11, at 325-27; see also NEWSWEEK, supra note 10, at 66 (citing improved inmate behavior in co-correctional prisons); Time, supra note 11, at 84 (citing less violence, greater participation in rehabilitative programs and increased self-esteem among inmates).

14. See U.S. Nat'l Advisory Comm'n on Criminal Justice Standards and Goals, CorRECTIONS 378-79 (1973) (Standard 11.6(7) \& Commentary) ("The correctional system should abandon the current system of separate institutions based on sex and develop a fully integrated system based on all offenders' needs."). See also AMERICan Correctional Ass'n, StandardS for Adult CoRrectional Institutrons 87 (1981) (Standard 2-4331) (recognizing practice of co-corrections). Some scholars have also advocated the use of co-correctional facilities. See, e.g., Resnik, supra note 9, at $109-10$.

15. Hudson v. Palmer, 104 S. Ct. 3194,3198 (1984).

Prison segregation necessarily involves the official, de jure segregation covered by the Fourteenth Amendment. The system of inmate assignments in a jurisdiction will be determined by statute, see, e.g., Colo. Rev. Stat. § 17-21-101(1) (1984 Supp.) (sentenced females to serve sentences at designated women's facility); GA. CODE ANN. $\S 42-5-52$ (c) (1982) (females to be removed from proximity to place of detention of males); N.C. GEN. STAT. $\$ 148-44$ (1983) (Department of Corrections shall separate male and female prisoners) or delegated to corrections officials by the legislature, see, e.g., IowA CODE ANN. $§ 902.5$ (West Supp. 1984-1985) (delegating assignment of prisoners to director of the lowa department of corrections); N.Y. CoRRECTION LAw § 72(1) (McKinney Supp. 1984-1985) (directing generally that all persons committed to the department of corrections be confined to institutions that it maintains).

Courts have made a de jure/de facto distinction for certain conditions in prison, primarily in the context of legal services provided to prisoners. In Glover $v$. Johnson, women and men were both found to have constitutionally adequate law libraries, but the men's library at the State Prison for Southern Michigan went beyond this minimum. 478 F. Supp. 1075, 1094-95 (E.D. Mich. 1979). The court refused to apply the parity standard; it noted that the inmates were able to decide how to spend certain funds and that the men chose to spend more on the library than did the women. Id. at 1095-97. This finding of de facto discrimination ignores the fact that the state was the source of the funds in both cases and the different amounts spent were determined in large part by the relative size of the institutions. The court ultimately permitted the assignment of an attorney to the women's facility at Huron Valley, but did so under a "meaningful access to courts" rationale, not an equal protection one. Id. at 1096-97. This distinction should be rejected in the context of a prison environment, where all actions are controlled, directly or indirectly, by the state.

16. Hudson v. Palmer, 104 S. Ct. at 3198; Washington v. Lee, 263 F. Supp. 327, 331 (M.D. Ala. 1966), aff d per curiam, 390 U.S. 333 (1968). This is true, in part, because an equal protection claim involves the comparison of two incarcerated groups, rather than the comparison of prisoners with persons at liberty. See Canterino v. Wilson, 546 F. Supp. 174, 213 (W.D. Ky. 1982).

17. If a classification is made on the basis of some neutral factor-one that does not classify on the basis of race, national origin, sex, alienage, or illegitimacy-it is subject to "rational basis" review. To 
scrutiny, ${ }^{18}$ and rigorous strict scrutiny. ${ }^{18}$ Gender classifications were once subject only to the lowest standard of review. ${ }^{20}$ Beginning with Reed $v$. Reed ${ }^{21}$ however, the Supreme Court recognized that the legal position of women often resembled that of racial or ethnic minorities and that more stringent review was needed to protect women's rights. Under the resulting intermediate level of judicial review, set forth in Craig $v$. Boren, ${ }^{22}$ the

survive this level of review, the classification need only bear a reasonable relationship to a legitimate legislative purpose. See, e.g., New York City Transit Auth. v. Beazer, 440 U.S. 568 (1979) (upholding blanket exclusion from employment of persons maintained on methadone); McGowan v. Maryland, 366 U.S. 420 (1961) (upholding Sunday closing law that provided for numerous exceptions).

18. Classifications made on the basis of sex or illegitimacy receive intermediate scutiny: The classification must be substantially related to an important state interest. See, e.g., Pickett v. Brown, 462 U.S. 1 (1983) (two-year statute of limitations on paternity and support actions on behalf of illegitimate children violates equal protection); Craig v. Boren, 429 U.S. 190 (1976) (lower drinking age for women than for men violated equal protection).

19. Classifications based on race are subject to strict scrutiny, which requires the government to establish that the classification is necessary to the accomplishment of a compelling state interest. See, e.g., Loving v. Virginia, 388 U.S. 1 (1967) (invalidating antimiscegenation law); McLaughlin v. Florida, 379 U.S. 184 (1964) (invalidating criminal statute prohibiting interracial cohabitation).

A classification that infringes on a "fundamental right" is also subject to strict scrutiny. See Shapiro v. Thompson, 394 U.S. 618 (1969) (right to travel); Reynolds v. Sims, 377 U.S. 533 (1964) (right to vote). The fundamental rights branch of the equal protection clause is not available to inmates challenging the lack of rehabilitation in prison because the courts have not recognized a fundamental right to rehabilitation. See Newman v. Alabama, 559 F.2d 283, 291 (5th Cir. 1977), rev'd on other grounds per curiam sub nom. Alabama v. Pugh, 438 U.S. 781 (1978).

Equal protection analysis distinguishes between facial classifications and non-facial classifications. Non-facial classifications are subject to elevated scrutiny only if they have a disparate impact on a protected group and are motivated by discriminatory intent. Personnel Administrator v. Feeney, 442 U.S. 256, 272-74 (1979). Proof of discriminatory intent should not be required for facial classifications, since intent to differentiate can be presumed from the explicit use of a characteristic such as race or sex. A system of inmate assignments on the basis of gender is such a facial classification. Thus, it is not necessary to prove discriminatory animus on the part of state legislators or prison administrators in order to invalidate the classification.

20. See, e.g., Goesaert v. Cleary, 335 U.S. 464 (1948) (upholding state law prohibiting women from bartending unless they were wives or daughters of male owners); Williams v. McNair, $316 \mathrm{~F}$. Supp. 134 (D.S.C. 1970), aff d mem., 401 U.S. 951 (1971) (upholding provision of single-sex secondary education).

21. 404 U.S. 71 (1971) (invalidating state probate statute giving preference to men over equally qualified women for appointment as administrators of estates).

Subsequent cases in which the Court has compared the position of women to other disadvantaged groups include Mississippi Univ. for Women v. Hogan, 458 U.S. 718, 725 n.10 (1982); Kahn v. Shevin, 416 U.S. 351, 357 (1974) (Brennan, J., dissenting); Frontiero v. Richardson, 411 U.S. 677, 685,688 (1973) (opinion of Brennan, J.). Several Justices have argued that the comparison between racial and sexual discrimination requires strict scrutiny for gender classifications. See Kahn, 416 U.S. at 357 (Brennan, J., dissenting); Frontiero, 411 U.S. at 682 (opinion of Brennan, J., in which Justices Douglas, White, and Marshall joined).

22. 429 U.S. 190, 197 (1976). The reasons why a less stringent standard of review should be used for sex than is employed for race have not been clearly articulated. Judicial hesitancy to use the most demanding level of review appears to stem from the belief that significant differences between men and women provide some legitimate bases for differentiation. This reticence is unjustified, in part because equal protection doctrine has a mechanism for handling such differences, although it has not been coherently applied: If differences are legally relevant, they can render the groups not "similarly situated" for the purposes of the classification. See Parham v. Hughes, 441 U.S. 347, 354-57 (1979) (upholding statute that allowed only those fathers who had legitimated their illegitimate children and mothers to sue for wrongful death of child; fathers who had not legitimated their children not similarly situated with mother or with father who had legitimated child). In cases where the groups are 
government bears the burden of establishing that a gender classification has an important purpose and that the relationship between purpose and classification is substantial. ${ }^{23}$

In Mississippi University for Women $v$. Hogan, ${ }^{24}$ the most recent articulation of the intermediate standard ${ }^{26}$ the Supreme Court employed a demanding version of the Craig test. The Court found that the womenonly enrollment policy of the university's nursing school denied a male applicant equal protection. Like cases invalidating racial segregation, $\mathrm{Ho}-$ gan emphasized the seriousness of stigmatic harms to women resulting from facial gender classifications. ${ }^{26}$ Because the classification at issue in Hogan imparted a stigma, the Court was willing to use a standard approaching strict scrutiny in its intensity. ${ }^{27}$ In its analysis, the Court closely examined the proffered governmental objective ${ }^{28}$ and required a tight fit

found to be differently situated, the Court made only a cursory analysis of legislative purpose and no analysis whatsoever of the means chosen. See Michael M. v. Sonoma County Superior Court, 450 U.S. 464, 478-81 (1981) (Stewart, J., concurring); Schlesinger v. Ballard, 419 U.S. 498, 507-10 (1975). Rather than avoiding the issue of differences, courts should confront it directly; if they determine that sex differences have a role in equal protection analysis, they must articulate a standard of what constitutes a relevant difference. In so doing, the courts should be cautious in their identification of constitutionally relevant differences. In particular, they should be wary of differences resulting from past discrimination. At a minimum, the "similarly situated" analysis should not encompass socially constructed differences or discrimination will be self-perpetuating. For a critique of the "similarly situated" analysis in sex discrimination cases, see C. MacKinnon, Sexual Harrassment of WORKING WOMEN 107-16 (1979).

Another reason why classifications based on gender have not been subject to strict scrutiny is that women have not been considered a "discrete and insular minority," see United States v. Carolene Products Co., 304 U.S. 144, 152 n.4 (1938). Because they are not a numerical minority, women are presumed to have the ability to protect their own interests through the political process.

23. See Mississippi Univ. for Women v. Hogan, 458 U.S. 718, 724 (1982).

24. 458 U.S. 718 (1982).

25. In Rostker v. Goldberg, 453 U.S. 57 (1981), the Court upheld men-only draft registration requirements. It employed a considerably weaker version of intermediate scrutiny than was used in Hogan. Rostker was not cited in Hogan and should be limited to the military context in which it arose.

26. 458 U.S. at 729-30. The dissent characterized the controversy in Hogan as follows: "His claim, it should be recalled, is not that he is being denied a substantive educational opportunity, or even the right to attend an all-male or a coeducational college . . . . It is only that the colleges open to him are located at inconvenient distances." 458 U.S. at 741-42 (Powell, J., dissenting) (footnotes omitted; emphasis in original). The majority, on the other hand, approached the problem more broadly, focusing on the generalized harm to women from a classification that perpetuates the stereotype that only women should become nurses, 458 U.S. at 729-30. See also Dimond, The Anti-Caste Principle-Toward a Constitutional Standard for Review of Race Cases, 30 WAYNE L. REv. 1, 39 (1983) (characterizing Hogan as stigma case).

27. The majority in Hogan did not apply strict scrutiny; it specifically declined to decide "whether classifications based upon gender are inherently suspect." 458 U.S. at 724 n.9. This appears to reopen the issue originally resolved in Craig v. Boren, 429 U.S. 190 (1976).

28. The Court demonstrated an unwillingness to accept without support an "affirmative action" justification:

Care must be taken in ascertaining whether the statutory objective itself reflects archaic and stereotypic notions. Thus, if the statutory objective is to exclude or "protect" members of one gender because they are presumed to suffer from an inherent handicap or to be innately inferior, the objective itself is illegitimate.

458 U.S. at 725 (citation omitted). The Court also sought to determine whether the stated objective 
between the purpose and the classification. ${ }^{29}$ This focus on the relationship between classification and purpose would invalidate most segregation. Segregative classifications are usually overbroad and less restrictive methods of classification are usually possible.

Strict scrutiny requires the examination of less restrictive alternatives to determine whether the classification is necessary to the state's compelling interest. ${ }^{30}$ Intermediate scrutiny has not consistently required the consideration of less restrictive alternatives to sex-based classifications, although such a requirement has been included in some formulations of the standard and has appeared in numerous dissenting opinions. ${ }^{31}$ Consideration of less restrictive alternatives is one of the best means of assuring a factor stressed in Hogan: the substantiality of the relationship betwen the classification and the objective. ${ }^{32}$ The method should be employed to review gender classifications. As will be discussed in Part IV, an alternative system of prison assignments could be based on factors other than sex that relate more directly to the needs of the inmate and the penal institution: offense-type, length of sentence, location of family, and educational and vocational interests.

For the equal protection clause to invalidate a classification, the classification must distinguish between groups that are "similarly situated." ${ }^{3}$ Until recently, prison segregation was supported by the view that women

was the actual objective of the classification. 458 U.S. at 728-29. This contrasts with the Court's willingness to accept some questionable statutory purposes in other cases. See, e.g., Michael M. v. Sonoma County Superior Court, 450 U.S. 464, 470 (1981) (plurality opinion) (upholding statutory rape law applying only to men on grounds that because all harmful non-criminal effects of teenage pregnancy fall on female, it is legitimate to punish male participant).

29. "The purpose of requiring that close relationship is to ensure that the validity of a classification is determined through reasoned analysis rather than through the mechanical application of traditional, often inaccurate, assumptions about the proper roles of men and women." 458 U.S. at 725-26 (footnote omitted).

30. San Antonio Indep. School Dist. v. Rodriguez, 411 U.S. 1, 16-17 (1973).

31. "Where, as here, the State's compensatory and ameliorative purposes are as well served by a gender-neutral classification as one that gender classifies and therefore carries with it the baggage of sexual stereotypes, the State cannot be permitted to classify on the basis of sex." Orr v. Orr, 440 U.S. 268, 283 (1979); see also Michael M., 450 U.S. 464, 490 (1981) (Brennan, J., dissenting): "The burden is on the government to prove both the importance of its asserted objective and the substantial relationship between the classification and that objective. . . . And the State cannot meet that burden without showing that a gender-neutral statute would be a less effective means of achieving that goal." (citations omitted).

32. 458 U.S. at 726. In Hogan, the Court did not have to decide the issue of less restrictive alternatives, since it found that Mississippi clearly failed to satisfy either the "important state interest" or the "substantially related" components of intermediate scrutiny. 458 U.S. at 731.

33. See Michael M., 450 U.S. at 469 (plurality opinion). Where race is concerned, the courts have recognized that no differences could situate the races dissimilarly. Id. at 478 (Stewart, J., concurring). While the courts have attributed legal significance to certain differences between men and women, $i d$., doctrine in this area remains confused. While it can be argued that a finding that the sexes are different may allow some classifications to be made, consistent with equal protection, it should not, however, justify a weaker standard of review once the groups are found to be similarly situated for the purposes of the classification. See supra note 22. 
offenders were fundamentally different from their male counterparts and that they required a different-and separate-system of rehabilitation. ${ }^{34}$ The differences between male and female prisoners, however, result from incarceration in very different institutions, ${ }^{\mathbf{3 5}}$ or reflect the particular characteristics associated with female crime. ${ }^{36}$ The former is attributable to the classification itself, ${ }^{37}$ while the latter is at least partly a consequence of the different treatment of women in the criminal justice system. ${ }^{38}$ Because they can be traced to official discrimination, these differences cannot render men and women dissimilarly situated with respect to incarceration.

\section{B. Approaches to Segregation}

Judicial review of offical segregation began with the separate but equal doctrine. In Plessy $v$. Ferguson, ${ }^{\mathbf{3 \theta}}$ the Supreme Court upheld a state statute requiring the racial segregation of railroad cars. The rationale for this decision was the perceived lack of cognizable harm to the black minority, assuming the facilities were "equal." Mo More than half a century later, the Court in Brown v. Board of Education"1 found segregated public education to be "inherently unequal" and, thus, unconstitutional. The school systems compared in Brown were objectively equal or were in the process

34. See State v. Heitman, 105 Kan. 139, 181 P: 630 (1919).

This view also produced differential sentencing statutes in effect in a number of states until the last decade. These statutes allowed women to receive indeterminate sentences, while men would receive determinate sentences for similar offenses. See generally Comment, Sex and Sentencing, 26 Sw. L.J. 890 (1972) (describing disparate sentencing practices for men and women and recommending greater judicial accountability in sentencing process).

Such provisions were based on unsubstantiated theories of female criminality and on the supposedly greater potential for rehabilitating women. See State v. Heitman, 105 Kan. at 147, 181 P. at 634 (justifying the imposition of an indeterminate sentence for women, but not men, because "the female offender not merely requires, but deserves, on account of matters touching the perpetuation and virility of the human species, correctional treatment different from the male offender, both in kind and in degree....")

These sentencing statutes have been held unconstitutional, see Commonwealth v. Daniel, $430 \mathrm{~Pa}$. 642,243 A.2d 400 (1968) (differential sentencing provision violated equal protection clause), but their view of the female offender as fundamentally "different" persists.

35. See generally V. Williams \& M. Fish, Convicts, Codes and Contraband: The Prison LIFE OF MEN AND WOMEN (1974) (male and female prison subcultures recognized as different; women inmates' activity centered around pseudo-family relationships more than did men's); Van Wormer, Social Function of Prison Families: The Female Solution, 9 J. Psychiatry \& LAw 181 (1981) (creation of make-believe families as reaction to incarceration in women's prisons).

36. For example, the non-violent nature of typical criminal activity distinguishes female from male offenders. C. FEINMAN, supra note 6, at 14-17; Nagel \& Hagan, supra note 6, at 94.

37. To consider differences resulting from the segregation itself would be comparable to justifying segregating black and white children in school because the "inferior" educational attainments of black children, resulting from the years of inferior education in segregated schools, made them unable to compete with their white peers.

38. See supra note 6 (discussion of "chivalry" in criminal justice system).

39. 163 U.S. 537 (1896).

40. Id.

41. 347 U.S. 483 (1954), supplemented, 349 U.S. 294 (1955). 
of being equalized, ${ }^{42}$ but the Court found that the segregation itself imposed irreparable harm on the black minority, marking them as inferior. ${ }^{43}$ Despite the narrowness of its reasoning, Brown has been extended to invalidate racial segregation in all public institutions, including prisons. ${ }^{44}$ The courts now presume that a segregative classification imposes stigma on the racial minority.

The Supreme Court has not determined whether separate but equal is a legitimate constitutional standard to apply to all classifications that segregate on the basis of sex. ${ }^{45}$ To date, the issue of sex-based segregation has been addressed exclusively in the field of education. ${ }^{48}$ The only postBrown case to apply separate but equal analysis, Vorchheimer $v$. School District of Philadelphia, ${ }^{47}$ permitted sex segregation. Vorchheimer was affirmed by an equally divided Supreme Court, without opinion. In any event, the arguments made in favor of the continuation of segregated education do not apply to penal facilities. Choice and diversity are the values advanced to justify segregation in education; 48 neither can support separate prisons for men and women. First, prisoners are not free to choose their prison assignments. ${ }^{48}$ Second, segregated prisons do not increase the

42. 347 U.S. at 492 .

43. "To separate them from others of similar age and qualifications solely because of their race generates a feeling of inferiority as to their status in the community that may affect their hearts and minds in a way unlikely ever to be undone." Id. at 494.

44. Washington v. Lee, 390 U.S. 333 (1968) (per curiam) (prisons); New Orleans City Park Improv. Ass'n v. Detiege, 358 U.S. 54 (1958) (per curiam) (parks); Gayle v. Bowder, 352 U.S. 903 (1956) (per curiam) (buses); Holmes v. City of Atlanta, 350 U.S. 879 (1955) (per curiam) (golf courses); Mayor of Baltimore v. Dawson, 350 U.S. 877 (1955) (per curiam) (beaches).

Martin Luther King, Jr. captured this view of racial segregation: "All segregation statutes are unjust because segregation distorts the soul and damages the personality. It gives the segregator a false sense of superiority and the segregated a false sense of inferiority." M. KING, Letter from Birmingham Jail, in WHY WE CAN'T WAIT 77, 85 (1964). See also Black, The Lawfulness of the Segregation Decisions, 69 YALE L.J. 421, 428 (1960) ("The Fourteenth Amendment commands equality, and segregation as we know it is inequality."); Dimond, supra note 26, at 25 (Brown adopted "a constitutional standard akin to the anti-caste principle-the right of every black person to be free from a caste system of compulsory segregation").

45. 458 U.S. 718,720 n.1 (1982). The Court noted that it was not deciding the issue of separate but equal educational institutions, since there was no other single-sex public university in the state.

46. See, e.g., Vorchheimer v. School Dist. of Philadelphia, 532 F.2d 880 (3d Gir. 1976), affd by an equally divided Court, 430 U.S. 703 (1977) (separate high schools); Williams v. McNair, 316 F. Supp. 134 (D.S.C. 1970), affd mem., 401 U.S. 951 (1971) (separate colleges).

47. 532 F.2d 880 (3d Cir. 1976), affd by an equally divided Court, 430 U.S. 703 (1977).

48. Mississippi Univ. for Women v. Hogan, 458 U.S. 718, 736-42 (Powell, J., dissenting). Cf. Resnik, supra note 9, at 116 ("Colleges are poor and inexact models for prisons.").

49. This is particularly true when there is only one women's prison in a jurisdiction, as is frequently the case. See generally ACA 1984 DireCTORY, supra note 7 (listing penal facilities by jurisdiction; noting gender of population).

In his dissent in Hogan, Justice Powell sought to distinguish between the type of segregation in Plessy and the tradition of separate educational facilities for women. Segregated prisons more closely resemble his description of the Plessy-type segregation: "It was characteristic of racial segregation that segregated facilities were offered, not as alternatives to increase the choices available to blacks, but as the sole alternative." 458 U.S. at 741 n.9 (emphasis in original). 
diversity of institutions available, because such institutions represent the only form of incarceration for women in most jurisdictions.

The proper analogy for sex segregation is, in fact, race, not education. The reason that led to the rejection of separate but equal for race-the recognition of the harm inflicted by official segregation-must also lead to the categorical invalidation of such sex-based segregation. The analogy between the suspectness of racial classifications and those based on gender should prove more persuasive where total separation is involved. ${ }^{50}$ Segregation, particularly in an environment as controlled and coercive as a prison, is a very different form of classification from, for example, the differential imposition of administrative burdens or the uneven distribution of monetary benefits. Our historical and cultural predisposition for mixing and mainstreaming ${ }^{51}$ establishes a strong presumption against separation of one group from another on the basis of any immutable characteristic. $^{\mathrm{S2}}$

\section{Burdens Imposed By Segregation}

\section{Stigma}

Following a long line of cases establishing judicial concern for stigmatic injury to women, ${ }^{63}$ Hogan requires courts to consider the harm inherent in separation. Despite these precedents, the segregation of women prisoners is often described in terms that, like Plessy, take a narrow view of the harm resulting from segregation. For example, in Glover v. Johnson, ${ }^{54}$ a

50. For a forceful statement of the analogy between the separate but equal classifications on the basis of sex and those on the basis of race in the context of single-sex public education, see Comment, Plessy Revived: The Separate But Equal Doctrine and Sex-Segregated Education, 12 HaRv. C.R.-C. L. L. REv. 585, 620-25 (1977). In the context of education, the analogy to Brown is, of course, most persuasive. Nevertheless, the holding in Brown should not be restricted to equal educational opportunity; Brown rests on a concept of stigmatic harm imposed by all public segregation.

51. Mainstreaming involves the mixing of a population otherwise considered "different" in a normal, non-segregated environment. The Education for All Handicapped Children Act, 20 U.S.C. $\S \S$ 1400-1406 (1982), exemplifies the mainstreaming approach applied to educating the handicapped. The Act establishes a preference for educating handicapped children in the public school system, along with their peers.

52. Frontiero v. Richardson, 411 U.S. 677, 686 (1973) (plurality opinion) ("sex, like race and national origin, is an immutable characteristic determined solely by the accident of birth").

53. See Parham v. Hughes, 441 U.S. 347, 354 (1979) ("IA] State is not free to make overbroad generalizations based on sex . . . which demean the ability or social status of the affected class."); Orr v. Orr, 440 U.S. 268, 283 (1979) ("Legislative classifications which distribute benefits and burdens on the basis of gender carry the inherent risk of reinforcing stereotypes about the 'proper place' of women and their need for special protection."); Kahn v. Shevin, 416 U.S. 351, 357 (1974) (Brennan, J., dissenting) ("IG]ender-based classifications too often have been inexcusably utilized to stereotype and stigmatize politically powerless segments of society."); Frontiero v. Richardson, 411 U.S. 677, 686-87 (1973) (opinion of Brennan, J.) ("IS]tatutory distinctions between the sexes often have the effect of invidiously relegating the entire class of females to inferior legal status without regard to the actual capabilities of its individual members.").

54. 478 F. Supp. 1075 (E.D. Mich. 1979). 
case evaluating sex discrimination in the Michigan prison system, the court never reviewed the segregative aspect of the classification. ${ }^{55}$ No harm was perceived to flow from the separation itself; it represented a neutral system of inmate assignments.

Segregation in prison developed from inaccurate, paternalistic assumptions of the type that have been found to stigmatize in other contexts. ${ }^{56}$ The nineteenth-century movement to establish reformatories for women initiated the practice of prison segregation. The movement was based, in part, on a belief in the malleability of the female character. This trait meant that women were morally weaker than men, but, at the same time, they possessed a greater potential for rehabilitation. ${ }^{57}$ The reform effort considered separation of women from men essential to the rehabilitation of women, who could be salvaged only through physical isolation from corrupting moral influences and through the example of the "virtuous" women who staffed these new prisons. ${ }^{58}$ Traditional women's roles were the model for rehabilitative efforts; ${ }^{39}$ to this end the reformatories taught domestic skills and emphasized the duties to family. ${ }^{80}$

Perpetuation of a system that separates and isolates women offenders

55. The court observed that "[t]he classification in question is not on its face a legislative determination that female prisoners shall receive less extensive program choices than males . . . Rather, the classification merely assigns women prisoners to Huron Valley and male prisoners to other facilities." Id. at 1080 (citation omitted).

56. Equal protection cases often examine the history of institutions to determine the role of biases in their creation and perpetuation. See Hogan, 458 U.S. 718, 727 n.13, 730 n.16 (1982) (discussing history of Mississippi University for Women and situating it in context of state-sponsored higher education in Mississippi). This historical analysis has often been used in school desegregation cases, where historical practices, coupled with a failure to take affirmative action following Brown, create a presumption that present conditions reflect the continuing effects of past discrimination. Dayton Bd. of Educ. v. Brinkman, 443 U.S. 526 (1979); Columbus Bd. of Educ. v. Penick, 443 U.S. 449 (1979). Because discriminatory intent is not relevant here, see supra note 19 , the historical analysis is undertaken only to determine stigma.

57. C. Feinman, supra note 6, at 40-41, 42, 44; Rafter, Prisons for Women 1790-1980, in 5 Grime and Justice: An ANnual Review of Research 129, 154-55 (M. Tonry \& N. Morris eds. 1983).

The reformatory movement influenced the design and administration of numerous prisons for women, beginning with Indiana's in 1873. Rafter, supra, at 151. On the history of women's prisons, see Note, Female Offenders: $A$ Challenge to Courts and the Legislature, 51 N.D.L. REv. 827, 829-31 (1975); Note, Women's Prisons: Laboratories for Penal Reform, 1973 WIs. L. REv. 210, 212-19.

The reformatory movement was also a humanitarian reaction to the penitentiaries and jails of the day, in which all criminals were intermingled in appalling conditions. Rafter, supra, at 133-34. The reformers' motivation was, in part, a desire to protect women from the sexual and physical abuse of their guards and fellow (male) prisoners. See Rafter, supra, at 133-34; Comment, Women Prisoners: Freedom from Sexual Harassment-A Constitutional Analysis, 13 Golden Gate 667, 672-75 (1983).

58. C. Feinman, supra note 6, at 42-43; Rafter, supra note 57, at 154-55.

59. Fabian, supra note 5, at 5 .

60. C. FeInman, supra note 6 , at 44,45 ; Rafter, supra note 57 , at $156,160,162$. This tradition continues to influence the vocational programming of women's prisons. 
on the basis of their supposed moral weakness and aptitude for indoctrination stigmatizes women. It signals that the separation of women from the mainstream is an acceptable, even desirable, practice. The social role of prisons also enhances the stigmatic effect of sex segregation. Like the segregated schools in Brown, most prisons are intended to serve an educative, developmental function. ${ }^{61}$ Additionally, unlike a school, a segregated prison represents the only environment to which prisoners are exposed for the period of their incarceration, and it is a more controlled, coercive environment.

For the purpose of considering stigma, prisons cannot be viewed as isolated institutions; they must be viewed in the context of the criminal justice system as a whole. There are important equality values at stake in prisons that are not necessarily present in other public institutions; "equal justice for all" is a fundamental tenet of criminal justice. ${ }^{62}$ When a woman convicted of the same crime and sentenced to the same term of incarceration as a man receives her punishment in an inferior and separate institution, equal justice is a hollow promise to her, and respect for the evenhanded administration of justice diminishes as a consequence. ${ }^{63}$

\section{Inferior Programs and Services}

Incarcerated women are subject to discrimination resulting from facilities that are unequal as well as separate, producing harm that would be cognizable under even the separate but equal standard. The programs, facilities, and services available to women prisoners in this country's dual prison systems are inferior in number and quality to those offered to men. ${ }^{64}$ Because women constitute such a small percentage of all inmates, their facilities and opportunities will necessarily be much more limited than those available to the larger male prison population. The small number of prisons for women means that the facilities cannot be adapted to the incarceration-related needs of women in the way that they are for

61. "Rehabilitation, which is education in every sense, is one primary goal of imprisonment. That rehabilitative process for adults is at least as difficult and demanding as the educative process for children. One process should not suffer from greater obstacles to success than the other." McClelland v. Sigler, 327 F. Supp. 829, 831 (D. Neb. 1971), affd, 456 F.2d 1266 (8th Cir. 1972).

62. See Sokoloff \& Price, The Criminal Law and Women, in The CRIMINAL Justice System AND WoMen 9 (B. Price \& N. Sokoloff eds. 1982).

63. See McClelland, 327 F. Supp. at 831 (racially segregated prison).

64. See supra note 5 and accompanying text.

The situation in women's prisons can be compared to that in all-black, segregated schools in the pre-Brown south. The quality of education offered to black school children was inferior in fact, as well as in the public's perception. The courts recognized this in the higher education cases leading up to Brown: McLaurin v. Oklahoma State Regents, 339 U.S. 637 (1950) and Sweatt v. Painter, 339 U.S. 629 (1950). Similarly, separate women's educational institutions have been inferior to comparable men's schools. Comment, supra note 50 , at 611 . 
men, ${ }^{65}$ and that women will suffer greater dislocation from their families and friends. Even in those aspects of the prisons in which women are supposed to receive better treatment than men-the rural setting, smaller size, and less restrictive environment typical of women's facilities-each supposed benefit has significant negative consequences. ${ }^{66}$

\section{Diminished Rehabilitation and Reintegration}

A segregated prison system also burdens the rehabilitative process inherent in a system of limited sentencing. ${ }^{67}$ By confining most persons convicted of crimes for limited periods of time, even a retributive penal system

65. See supra note 9.

66. The isolated setting of many prisons, while aesthetically pleasing, disadvantages most women. Since crime is largely an urban phenomenon, most inmates will be from urban areas of the state. U.S. Dep'T OF JUSTICE, SOURCEBOoK OF CRIMINAL Justice Statistics-1982, at 391 (T. Flanagan \& M. McLeod eds. 1983) (table 4.2). Their imprisonment in a rural facility removes them from family, frequently including minor children, and friends. Lack of public transportation to the rural areas where women are incarcerated also inhibits maintaining contacts with the outside world and limits inmates' ability to establish a support network to assist them with problems encountered in prison and upon release.

The small size of neighboring communities limits the availability of educational opportunities, work release and other community-based programs. The small size of the prisons themselves also presents disadvantages discussed supra note 8 .

Women's prisons are designed differently than men's prisons. Security features-high fences, gun towers, and guard posts-are not used in most women's prisons. See Bukhari v. Hutto, 487 F. Supp. 1162, 1171 (E.D. Va. 1980) (description of Virginia Correctional Center for Women); AMERICAN Correctional Ass'N, Manual of Standards 560-61 (1966) (recommending that "evident" signs of security not be used in women's prisons). This policy results, however, in institutions that are costly to operate, siphoning into administration funds that are needed for rehabilitative programs. The costs must figure into institutional budgetary constraints and make corrections officials loath to spend or request more funds for rehabilitative programs for female offenders.

The lack of institutional security also disadvantages inmates classified as security risks. Such women are subjected to severe restrictions on their ability to move about an otherwise low security institution. See Bukhari, 487 F. Supp. at 1171 (plaintiff claimed equal protection rights violated by disparity between conditions of confinement in maximum security in women's prison and male maximum security facilities in state). This can result in indefinite periods in solitary confinement or perpetual shackling. One inmate at CCI-Niantic, who is an escape risk, is indefinitely restricted to the special management unit and wears leg irons and handcuffs at all times, except when her infant visits her, at which time the handcuffs are removed. Interview with T.L., conducted at CCI-Niantic (Dec. 12, 1983) (T.L. was in leg irons and handcuffs throughout interview).

67. See Newman v. Alabama, 559 F.2d 283, 291 (5th Cir. 1977) (no constitutional right to rehabilitation).

Prison systems and corrections experts have split between rehabilitation-oriented systems and punishment-oriented ones, with the current trend favoring the Iatter. See Frank, The American Prison: The End of an Era, Fed. Probation, Sept. 1979, at 3, 5. Because release follows incarceration for most prisoners, however, under any set of correctional objectives, society must be concerned about the reintegration of inmates into society, as a matter of sound policy, if not of constitutional theory.

To determine the goals of a correctional system, one can look to statements of legislative purpose. For example, New York has adopted a rehabilitative-reintegrationist correctional policy. N.Y. CoRRECTION LAW $\S 70$ (2) (McKinney Supp. 1984-1985). State v. Heitman, 105 Kan. 139, 143, 181 P. 630,632 (1919), gave a rather poetic description of a similar policy of the Kansas prison system: "[I]t is best for society . . . to try to float from off the rocks of the penal law and save, if possible, for future profitable voyaging, human vessels stranded there, whether by fog, or ill wind, or defective steering gear, or bad seamanship."

The absence of a federal constitutional right to rehabilitation may well prevent a federal court from 
cannot ignore the need to prepare inmates for reintegration into society. ${ }^{68}$ As a policy matter, sex segregation is inimical to reintegration because it produces an environment that does not correspond to the world that prisons are preparing inmates to reenter and makes the critical period of readjustment more difficult. ${ }^{69}$ The greater disruptions to the family lives of women inmates and the inferior vocational training available to women in prison present additional obstacles to the reintegration of female offenders. ${ }^{70}$

\section{Parity of Treatment}

The harms that result from the segregation of men and women in prison take many forms. Certain inequities, such as inferior programs and services, could be remedied within a segregated system, although at considerable cost. The remaining stigmatic harms, however, cannot be remedied while the system remains segregated. Courts that have reviewed claims of sex discrimination in prison have avoided confronting these harms. They have adopted a variant of equal protection analysis, the "parity of treatment" standard: "[W] hat the Equal Protection Clause requires in a prison setting is parity of treatment, as contrasted with identity of treatment, between male and female inmates with respect to the conditions of their confinement and access to rehabilitation opportunities." ${ }^{\prime \prime 1}$ As

enjoining state corrections officials from segregation in violation of state law or state correctional policy alone. See Pennhurst State School \& Hosp. v. Halderman, 104 S. Ct. 900, 911 (1984) (rationale of Ex parte Young, 209 U.S. 123 (1908), exception to Eleventh Amendment's prohibitions disappears when state officials' actions are claimed not to conform to state, as opposed to federal, law). The state courts, of course, remain open to hear such claims.

68. The process of rehabilitation is frequently described in terms of reintegration into society upon release from confinement. See Glover v. Johnson, 478 F. Supp. 1075, 1081 (E.D. Mich. 1979).

69. See Jacobs \& Steele, Sexual Deprivation and Penal Policy, 62 CoRnel. L. Rev. 289, 292-93 (1977). Much of the focus of co-correctional programs has been on this reintegration theme. See TIME, supra note 11, at 84 ("Our whole thrust is to get incarcerated people into a more normal environment. If it's not coed, then we're preparing them for a situation that they are not going to meet in life." (quoting Robert Vagts, Deputy Commissioner of Community Services in Massachusetts)); NEWSWEEK, supra note 10, at 66 ("'I feel better prepared for life now,' says Dalty Kimber, a Kansas prisoner eligible for parole next month. "A woman is not the premier thing anymore.").

70. See generally Zimbal, Hiring Women Ex-Offenders: What We Can Do, FEd. Probation, Sept. 1983, at 42 (identifying the particular employment problems of female ex-offenders).

71. Glover v. Johnson, 478 F. Supp. 1075, 1079 (E.D. Mich. 1979) (emphasis omitted). This parity standard was based on an unpublished case from the District of New Mexico, Barefield v. Leach, No. 10282 (D.N.M. 1974). See Glover, 478 F. Supp. at 1078-79. The parity standard was further explained in Glover:

Defendants here are bound to provide women inmates with treatment and facilities that are substantially equivalent to those provided men-i.e., equivalent in substance if not in form-unless their actions, though failing to do so, nonetheless bear a fair and substantial Id. relationship to the achievement of the State's correctional objectives.

Curiously, the Glover court viewed the reasoning in Barefield as "sound and fully consistent with Craig $v$. Boren, which followed two years later." Id. at 1079. In Bukhari v. Hutto, the Craig test was even reformulated in terms of parity: 
used by the courts, the concept of parity is a vague one; it has been defined only through conclusory examples or by negative implication. ${ }^{72}$

Not surprisingly, the parity standard has been inconsistently applied: Courts have treated parity claims raised by men less favorably than those raised by women; ${ }^{23}$ they have also subjected claims involving programs funded under statutes containing nondiscrimination provisions to a heightened standard of review. ${ }^{74}$ Furthermore, a comparative standard is ill-suited to the issues that arise in prison sex discrimination cases. The courts have not come to terms with the issues of differences between male and female inmate populations ${ }^{78}$-most notably size

Both de jure and de facto sex-based disparity has existed within the criminal justice system from arrest and sentencing procedures to incarceration and classification within the prisons. However, the Fourteenth Amendment requires, even in the context of prison conditions, that any disparity must "serve important governmental objectives" and must be "substantially related to the achievement of those objectives." 487 F. Supp. 1162, 1171 (E.D. Va. 1980) (footnote omitted).

A gender classification should be tolerated where "substantially related" to the achievement of an "important governmental objective," Craig, 429 U.S. at 197, but disparities will be upheld when they bear a "fair and substantial relationship to the purpose of the inmate's incarceration." Glover, $478 \mathrm{~F}$. Supp. at 1079 (quoting Barefield). Although the tying of a permissible disparity to the purpose of incarceration may allow individualized treatment of offenders or permit some states to have different correctional objectives from others, it also allows any correctional objective to satisfy the intermediate standard of review, which is not what equal protection law requires.

The purpose inquiry has not actually been used to justify disparities, however. Instead, the courts have found that the condition complained of was not a disparity. See, e.g., Glover, 478 F. Supp. at 1096.

72. The meaning of the term parity itself is not clear. The phrases "substantially equivalent" and "equivalent in substance, if not in form" which are used to define parity, Glover, $478 \mathrm{~F}$. Supp. at 1079 , do little to clarify its meaning. The one thing that is clear is that parity does not mean "identity of treatment." Id.

73. Parity claims asserted by male prisoners have been rejected without serious consideration. See, e.g., Madyun v. Franzen, 704 F.2d 954, 961-63 (7th Cir.), cert. denied, 104 S. Ct. 493 (1983) (male inmate found not to have been denied parity of treatment when frisked by woman security guard, even though women were not permitted to be frisked by male guards); Hill v. Estelle, 537 F.2d 214 , 215-16 (5th Cir. 1976) (no disparity with respect to different hair length, cell decoration, and telephone rules in men's and women's prisons).

74. These programs include those receiving funds under the Omnibus Crime Control and Safe Streets Act of 1968, 42 U.S.C. § 3789d(c)(1) (1982) (establishing the Law Enforcement Assistance Agency (LEAA)) and Title IX of the 1972 Education Amendments, 20 U.S.C. $§ 1681$ (a) (1982). The statutes do not specifically include prisons within the purview of their nondiscrimination provisions, but they do not specifically except them either. The court in Canterino $v$. Wilson (I) found that the statutes were applicable, but limited by the parity analysis. 546 F. Supp. 174, 209-10 (W.D. Ky. 1982). Where federal funds were received under statutes containing nondiscrimination provisions, prisons were held to a higher standard of "equivalent programs in form as well as in substance." Id. at 210 (emphasis in original). A co-correctional remedy was not required, even where federal funds were directly involved, only " $a$ consistent good faith effort must be made to include female inmates in the benefits of all programs funded in part with federal dollars." Id.

75. There are differences between the two inmate groups. By applying the parity analysis, however, the courts have recognized that such differences are not of sufficient magnitude to bar equal protection claims. Nonetheless, they have had difficulty confronting the differences issue within the confines of parity analysis.

The magnitude and origin of differences are particularly relevant to the fashioning of remedies by the courts. Differences have proved most troublesome in the area of law libraries and access to courts. Women do not have a tradition of jailhouse lawyers who can assist their fellow inmates in the pursuit of post-conviction remedies, and they have not regularly filed habeus corpus petitions or civil rights 
differentials ${ }^{76}$-and the role of inmate preferences, ${ }^{77}$ yet parity requires them to make comparisons between groups that are different in important respects and may have distinct preferences.

At a minimum, however, parity represents a less stringent version of a separate but equal test. Not only does parity, like separate but equal, refuse to recognize harms resulting from the process of segregation itself, it does not even demand that separate prison facilities be equal. Furthermore, parity permits a court to exercise only limited remedial powers: It rejects institution-wide integration as a remedy for disparities ${ }^{78}$ and, in so doing, denies women inmates their only realistic opportunity for equal treatment.

Courts that employ parity nevertheless do not acknowledge that they

suits. Alpert, Women Prisoners and the Law: Which Way Will the Pendulum Swing?, in THE CRIMINAl. JUSTICE SYSTEM AND WOMEN, supra note 62, at 171, 173. Thus, even supplying library resources identical to those available to men would not provide a "parity" of access to the courts. The courts have provided some additional resources to women under a "meaningful access to courts" theory, rather than an equal protection one. E.g., Glover, 478 F. Supp. at 1095-97. While it does recognize the existence of differences and the role of past discrimination in their creation, a "meaningful access" theory ensures only a minimal level of services; it does not attempt to provide parity with men, many of whom have developed considerable expertise and have access to better libraries and to the assistance of knowledgeable fellow inmates.

76. The huge size differential between the male and female inmate groups renders the two incomparable in significant respects. See Glover, 478 F. Supp. at 1078. Although comparisons based on size alone have been rejected, see id., the courts have not specified what the relevant institutional comparisons should be or why they are using a particular men's prison for comparison for any particular claim. In Barefield, the source of the parity standard, women had challenged inequalities in the women's division of a larger facility for men; the court presumably felt that the relevant comparison was with the men's section of the same prison. Glover sought to transplant that standard into the context of a comparison of an entirely separate women's prison with a number of men's prisons.

77. By considering preferences, the courts have deviated from the usual practice in cases involving constitutional violations. When confronting an unconstitutional condition, courts ordinarily attempt to remedy it, without directly considering the preferences of the victim class. See, e.g., Swann v. Charlotte-Mecklenburg Bd. of Educ., 306 F. Supp. 1291, 1293 (W.D.N.C. 1969) (objections of blacks, as well as whites, did not overcome the dictates of the Constitution). Swann involved protracted school desegregation litigation: A plan was adopted by the district court, 311 F. Supp. 265 (W.D.N.C. 1970), vacated in part by the court of appeals, 431 F.2d 138 (4th Cir.), but reinstated by the Supreme Court, 402 U.S. 1 (1971); see also Green v. County School Bd., 391 U.S. 430, 439 (1968) ("freedom of choice" plan rejected; seen as only a means to achieve constitutionally mandated desegregation, not an end in itself). Furthermore, such preferences will usually be influenced by past discrimination. See P. Gewirtz, Choice in the Transition 21-30 (March 20, 1985) (unpublished manuscript).

The issue of preferences has arisen primarily as a justification offered by prison officials for their failure to provide programs for women. For example, they have maintained that there is insufficient interest in them or no interest at all. See Batton v. North Carolina, 501 F. Supp. 1173, 1178 (E.D.N.C. 1980). In some cases, the assertions are made in bad faith: Prison administrators have not made a serious effort to ascertain interest, citing as evidence only the unpopularity of existing programs that were not well publicized or explained to the inmates. See, e.g., id.; Glover, 478 F. Supp. at 1086. Parity should not turn on the preferences of female inmates in circumstances where men's preferences are not accommodated. Similarly, if the different amount of interest of male and female inmate populations is attributable to the size of the two groups, this is also an illegitimate consideration.

78. See, e.g., Glover, 478 F. Supp. at 1078. 
are applying a diminished level of judicial scrutiny. ${ }^{79}$ The reasons for deviating from routine equal protection analysis for women in prison may reflect the traditional deference given to prison officials in the administration of prisons, ${ }^{80}$ and an exaggerated concern for the danger of integration to women. Significantly, this deferential posture was overcome in cases involving racial segregation; similar security concerns were not allowed to limit the appropriate remedy in those cases. ${ }^{81}$

\section{Hogan Applied to Segregated Prisons}

Although segregative classifications should be subject to strict scrutiny, the gender-based segregation of prisons is unconstitutional even under the intermediate standard of review, as articulated and applied in Hogan. Identifying an important governmental objective for segregation is the first step in such analysis. Various objectives have been advanced to support prison segregation: the cost of co-correctional facilities, the special needs of women inmates, the privacy rights of incarcerated women, and prison security. The relationship between any of these objectives and sex segregation is not sufficiently substantial to withstand intermediate scrutiny.

\section{A. Cost}

The cost objective can be dismissed, since cost per se is not recognized as a sufficiently important governmental objective to justify unequal treat-

79. In Glover, the court proceeded from a recitation of the proper standard of review to an examination of the proper scope of remedy available: "The question remains, however, whether the usual remedy in cases dealing with discriminatory classifications-i.e., the extension of benefits to the class previously excluded by the classification-is appropriate in this context." 478 F. Supp. at 1078.

Though it is characterized as a remedial limitation, parity analysis actually results in a reformulation of the rights of women prisoners: A woman in prison is entitled only to parity, not equality.

80. Jones v. North Carolina Prisoners' Union, 433 U.S. 119, 127 (1977). This deference expresses concern for the competence of the judiciary to intervene in the technical, policy-laden area of corrections. "[G]ourts are ill equipped to deal with the increasingly urgent problems of prison administration and reform." Procunier v. Martinez, 416 U.S. 396, 405 (1974) (footnote omitted). Even where this deferential posture is overcome, in cases involving substantial constitutional violations, the courts will often defer to the defendant correctional authorities to formulate remedial plans. See Canterino II, 562 F. Supp. 106, 115 (W.D. Ky. 1983).

Federalism has also been invoked to avoid more stringent review of prison conditions, where the federal courts are asked to interfere with the operation of state prison systems. See Procunier v. Martinez, 416 U.S. 396, 405 (1974).

81. See, e.g., McClelland v. Sigler, 327 F. Supp. 829, 832-34 (D. Neb. 1971), affd, 456 F.2d 1266 (8th Cir. 1972); Washington v. Lee, 263 F. Supp. 327, 331-32 (M.D. Ala. 1966), affd per curiam, 390 U.S. 333 (1968). 
ment. ${ }^{82}$ The courts that have considered this justification for disparity in the treatment of incarcerated men and women have rejected it. ${ }^{83}$

\section{B. Special Needs}

Sex segregated prisons have been justified as essential to provide for the special needs of women inmates, such as health care requirements (particularly those relating to pregnancy) and needs as parents. These special needs cannot truly justify the classification, however, since they are rarely satisfied in a sex segregated prison. Because of the small size of women's prisons, the health care they provide tends to be rudimentary, especially for pregnant inmates. ${ }^{84}$ The needs of women as parents are also frequently ignored. ${ }^{85}$ Most jurisdictions do not permit inmates to keep their infants with them and thus do not provide special nursery facilities for inmate mothers. The remote location of many women's prisons makes contact between a mother and her children very difficult. ${ }^{86}$ In any case, the needs of inmates as parents are not unique to women. Incarcerated men also have families, although society has traditionally discounted the father's role in childrearing and his emotional reaction to separation from his children.

82. Gates v. Collier, 501 F.2d 1291, 1319-20 (5th Gir. 1974) (citing cases).

Cost is essentially an administrative convenience justification of the sort that has been rejected in many other contexts. See, e.g., Califano v. Goldfarb, 430 U.S. 199, 211 n.9 (1977). Under a cost objective, sex is the only characteristic that need be considered in assigning women to prison. It replaces, for women, characteristics considered relevant in making prison assignments for men, such as offense-type, security designation, and length of sentence. Use of these characteristics would impose administrative burdens that do not now exist.

83. "A desire to preserve the state's limited resources cannot be used to justify an allocation of those limited resources which unfairly denies women equal access to programs routinely available to men." Canterino I, 546 F. Supp. at 211 (citation omitted; emphasis in original); see also McMurry v. Phelps, 533 F. Supp. 742, 767 (W.D. La. 1982) (lack of funds insufficient justification for failure to make less restrictive facilities available to women).

84. For example, most women's prisons are not equipped with complete on-grounds medical facilities or a full-time medical staff. Fabian, supra note 5 , at 18.

85. A majority of incarcerated women are mothers. See U.S. DEP'T OF JUSTICE, SOURCEBOoK OF Criminal Justice Statistics-1978, at 638 (N. Parisi, M. Gottfredson, M. Hindeland \& T. Flanagan eds. 1979) (table 6.44). On the average, $73.2 \%$ of incarcerated women had one or more children and for those who had children, the mean number was 2.48. Significantly, comparative figures for incarcerated men were not available. Despite these facts, few prisons have programs aimed at inmate-mothers.

86. C. Feinman, supra note 6, at 14-17.

Many inmate-parents have particular legal needs relating to the custody of their children, since incarceration can result in the termination of parental rights in some states. See Note, The Loss of Parental Rights as a Consequence of Conviction and Imprisonment: Unintended Punishment, 6 NEw ENG. J. PRISON L. 61 (1979). Yet, in many prisons, legal services available to women do not include representation in custody matters. See Canterino I, 546 F. Supp. at 203. 


\section{Privacy}

Some sex-based segregation has been tolerated as necessary to protect the right to privacy. ${ }^{87}$ Privacy is also a false basis for segregation, however, in part because it is one right that is necessarily diminished by incarceration. ${ }^{88}$ In addition, the privacy interests of women prisoners are already significantly compromised by the presence of male guards. ${ }^{89}$ Demonstrating the type of stereotypical assumptions disapproved in $\mathrm{Ho-}$ gan, courts have generally assigned a higher value to female modesty and a woman's need for privacy than to men's needs. ${ }^{90}$ As with the special needs justification, however, labeling privacy a women's issue ignores the fact that male prisoners also have privacy interests. ${ }^{91}$ Finally, prisons can deal with the privacy problems of men and women through alternatives less restrictive than segregation. ${ }^{92}$

87. The Supreme Court has recognized a fundamental right to privacy, the precise source and contours of which are not defined. See Roe v. Wade, 410 U.S. 113, 152-56 (1973) (right to privacy encompasses abortion decision, but is not absolute); Paris Adult Theatre I v. Slaton, 413 U.S. 49, 65-67 (1973) (right does not protect viewing of obscene movies in public theater).

88. See Hudson v. Palmer, 104 S. Ct. 3194, 3200-01 (1984) (right to privacy must be balanced against competing concerns of institutional security; inmates have no legitimate expectation of privacy in cells under Fourth Amendment).

89. The privacy issue has been litigated in the context of male guards in women's prisons and, to a lesser extent, women guards in men's prisons. In the former group of cases, the outcome has often rested on stereotypes of female modesty and a patronizing approach to the needs of women inmates. In Forts v. Ward, 621 F.2d 1210 (2d Cir. 1980), women inmates sought an injunction to prevent the assignment of male guards to duties that would include the observation of women at night, when they might be sleeping nude or partially clothed. Only on the second remand did the Court of Appeals deny the injunction, finding that the privacy rights could be protected by means less restrictive than prohibiting men from employment as guards. These included issuing concealing sleepwear to all inmates and allowing women to cover the windows on their cell doors for 15 minute intervals, while dressing or undressing.

90. A woman's supposedly greater need for privacy explains the design of many women's prisons. R. Glick \& V. NETo, supra note 5 , at 27.

91. The privacy rights of men have largely been ignored, as in Madyun v. Franzen, 704 F.2d 954, 961-63 (7th Cir.), cert. denied, 104 S. Ct. 493 (1983), where a male prisoner alleged that his right to privacy was violated when he was frisked by a female corrections officer. The court found the employment rights of women outweighed the inmate's privacy concerns. The plaintiff's equal protection argument was also rejected, despite the fact that there was a regulation in effect that allowed women inmates to be searched only by other women. Dothard v. Rawlinson, 433 U.S. 321 (1977), a Title VII case involving the employment rights of women guards, never mentioned the privacy rights of male inmates. But see Gunther v. Iowa State Men's Reformatory, 612 F.2d 1079 (8th Cir.), cert. denied, 446 U.S. 966 (1980) (privacy rights of male prisoners recognized, although not considered to constrain the employment rights of women; Dothard distinguished on its facts); Sterling v. Cupp, 290 Or. 611, 632, 625 P.2d 123, 136 (1981) (state constitution granted men protection from searches conducted by women guards that included touching of intimate body areas through clothing).

92. To ensure reasonable privacy for inmates of both sexes, administrators of co-correctional prisons could develop a system of rules restricting access to areas housing members of the opposite sex, at least in non-emergency situations without adequate notice. Similarly, guards and inmates could be prohibited from entering opposite sex bathrooms, except in emergencies.

Since the desegregation remedy proposed in Part IV does not contemplate the mixing of men and women in cells, elaborate procedures to ensure privacy would not be necessary in most cases, although this would depend on the design of the institution. 


\section{Prison Security}

The issue of prison security is the most significant justification for the separation of male and female prisoners. The security objective can be broken down into two components, both of which have been invoked to justify segregation: institutional security, which includes the adherence to internal rules and maintenance of prison order, and personal security, which encompasses the protection of inmates from assault by other inmates and guards. Although sometimes invoked pretextually, both aspects of the security justification are important governmental objectives. ${ }^{93} \mathrm{Be}$ cause sex-based segregation is not substantially related to achievement of these security objectives, however, the classification cannot be sustained under Hogan.

\section{Institutional Security}

While institutional security is an important interest, segregation is not related to its achievement in any self-evident way: Integration would not lead to an increase in escapes or to a deterioration in prisoner-guard relations. ${ }^{94}$ The transition to co-corrections might produce some disorder, but this would be temporary. The presence of women might even reduce tensions, since a co-correctional environment would more closely approximate the familiar environment of the outside world. The burden is on the state to produce evidence that would support its concern for prison security. ${ }^{95}$

The one factor perceived as a disciplinary problem in co-correctional prisons has been the prevalence of illicit sexual activity and even prostitution, although apparently not rape, in contravention of prison rules. ${ }^{96}$ This institutional security problem would be no greater than the homosexual activity that routinely occurs in single-sex prisons, ${ }^{97}$ activity that is tolerated and is not viewed as a serious threat to institutional security. The

93. See Hudson v. Palmer, 104 S. Ct. 3194, 3199 (1984) (recognizing "internal security" as chief among "institutional needs and objectives" of prisons that justify the loss or curtailment of rights, including Fourth Amendment rights); Bukhari v. Hutto, 487 F. Supp. 1162, 1172 (E.D. Va. 1980) (recognizing security as "valid concern" that could justify disparate treatment, but requiring further hearing to determine the merits of plaintiff's equal protection claim). But see Canterino I, $546 \mathrm{~F}$. Supp. at 212 (record does not support finding that security concerns prohibit use of specific cocorrectional programs to achieve parity).

94. There have been a relatively high number of escapes from FCI-Fort Worth, a co-correctional federal prison, but this is more likely attributable to the loose security at that institution than to its cocorrectional character. TIME, supra note 11 , at 84 .

95. See supra note 23.

96. V. Fox, supra note 10, at 168-69; Ruback, supra note 11, at 317-18.

97. V. Fox, supra note 10, at 168-69; see Fortune Society, How to Understand Sexual Assaults in Prisons and Jails, Criminal Justice NewsletTer, Apr. 28, 1980, at 2 (describing problem of rape and sexual assault in men's prisons). 
problem is simply not a significant enough breakdown of security to justify segregation.

\section{Personal Security}

Segregation is also not an effective means of assuring the personal security of women in prison. ${ }^{98}$ The problem of inmate assault is not unique to women in an integrated environment, but is common to male and female inmates in segregated prisons. ${ }^{99}$ Personal security is a function primarily of supervision, not segregation. Women can be more vulnerable in poorly supervised single-sex prisons than they are in co-correctional ones that are properly supervised. Furthermore, the current system is improperly implemented to achieve personal security: The lack of security classifications within women's prisons demonstrates a disregard for physical safety.

A fundamental error in the personal security justification is that it accepts the violent environment of men's prisons today as unalterable, despite the fact that such conditions are unlawful and are directly within the control of prison officials. To the extent that it relies on this incorrect premise, Dothard v. Rawlinson, ${ }^{100}$ a Title VII case denying female applicants prison guard positions in a men's maximum security prison, should be overruled. Washington $v$. Lee ${ }^{101}$ recognized that, in the context of racial segregation, the prison environment presents unique security concerns, but it does not justify a discriminatory system of incarceration. Washington $v$. Lee and subsequent race cases ${ }^{102}$ have sustained the importance of integration, even in a climate of overt hostility: Prison security can be used to justify only temporary separation under emergency conditions. ${ }^{103}$ Fear of uncontrolled violence, including sexual assault, does not justify discrimination on the basis of sex any more that it does on the basis of race. In Lee the court refused to relieve prison administrators of their duty to maintain order in the prisons and, in effect, demanded that less restrictive alternatives to segregation be used to accomplish the security objective. ${ }^{104}$ Threats to the safety of women should be handled similarly, through measures available to prison officials, such as using additional staff and taking

\footnotetext{
98. Comment, supra note 57 , at 667-72.

99. Fortune Society, supra note 97, at 2.

100. 433 U.S. 321 (1977). See discussion of Dothard, supra note 91.

101. 263 F. Supp. 327, 331-32 (M.D. Ala. 1966), affd per curiam, 390 U.S. 333 (1968).

102. See, e.g., McClelland v. Sigler, 327 F. Supp. 829 (D. Neb. 1971), affd, 456 F.2d 1266 (8th Cir. 1972).

103. See Washington v. Lee, 263 F. Supp. 327, 331 (M.D. Ala. 1966).

104. The holdings in McClelland and Lee are implicit determinations that there was not the requisite necessary relationship between the security objective and racial segregation. Where the threats of violence are less pronounced than they were in those cases, as they are in sexually integrated prisons, the constitutionally-required substantial relationship cannot be established either.
} 
prompt disciplinary action against inmates who assault, injure, or otherwise threaten their fellow inmates.

As a classification designed to achieve the personal security objective, segregation is overbroad. The protection of women rises to a level of sufficient importance only at higher security levels, where male inmates actually present a danger to others. Current statistics demonstrate that only a small percentage of women would fall into those classifications. ${ }^{105}$ The needs of these women, while they should not be ignored, cannot justify a system that applies to all inmates, regardless of their security designation. ${ }^{108}$ Lower security facilities, to which most women would be assigned, house men who are not considered violent and who by definition present a minimal danger to other inmates. The willingness of some corrections officials to experiment with co-corrections at low security levels acknowledges the diminished interest in protection at those facilities.

The security objective can be achieved through less restrictive alternatives to segregation. The success of experimental co-correctional prisons suggests that there is no inherent obstacle to the mixing of incarcerated men and women. Integrated systems have protected female inmates and have maintained reasonable institutional order and discipline. ${ }^{107}$ Thus, the

105. Chesney-Lind, supra note 6, at 197-98; Nagel \& Hagan, supra note 6, at 99-104.

106. A classification that improperly uses a non-neutral characteristic to achieve its purpose when a neutral characteristic would do so more accurately is overbroad; if the neutral characteristic would only be equally effective, the status of race or sex as disfavored bases for classification should also require the use of the alternative method of classification. See supra text accompanying notes 30-32.

The personal security rationale is also based on paternalistic concerns about the "weaker sex" and women's ability to survive the harsh environment of male prisons. A desire to protect women was one of the forces behind the reformatory movement. See supra note 57 . The "weaker sex" stereotype ignores the fact that not all women are weaker than all men. Sex is an overbroad classification for the characteristic of physical strength or aggressiveness.

This stereotype pervades the reasoning of Dothard v. Rawlinson, 433 U.S. 321 (1977). Dothard found sex to be a bona fide occupational qualification for employment as a prison guard in a men's maximum security prison. The protective rationale of Dothard at least should be limited to its facts: a particularly violent prison, where conditions had been found to be unconstitutional. Id. at 346-47. (Marshall, J., concurring in part and dissenting in part). At least one federal appeals court has so limited Dothard. See Gunther v. Iowa State Men's Reformatory, 612 F.2d 1079, 1085 (8th Cir.), cert. denied, 446 U.S. 966 (1980).

This analysis does not seek to minimize the problem of rape and assault that would undoubtedly follow the integration of certain prisons, if such integration were to occur without other systemic changes, such as mechanisms for allowing women to protect themselves, self-defense training, consistent punishment of rapists, the availability of adequate numbers of guards trained to handle the problems, the education of men and women in non-violent means of relating to one another, and strictly enforced rules barring men from entering areas where women are likely to be dressing, sleeping or otherwise vulnerable.

107. These experiments have been limited to low security inmates, see Ruback, supra note 11, at $314-17$, but most women would be given a low security classification. See supra text accompanying note 105 . 
allegedly substantial relationship of the security objective to the classification is undermined by the existence of co-correctional programs without significant breakdowns in prison security or danger to women prisoners. ${ }^{108}$

\section{The Co-Correctional Remedy}

The only remedy that will eliminate the unconstitutional segregation of prisons is a gender-neutral system of inmate assignment. The equalization of segregated facilities is inadequate, since it would not remedy either stigmatic or reintegrational harms. Equal access to rehabilitative services, programs and facilities, irrespective of gender, is the goal of a nondiscriminatory prison system. Different methods of achieving the goal of equal access would be permitted, allowing some latitude for local experimentation. By proposing a desegregation remedy, this Note does not suggest that women must simply adapt themselves to the existing structure of men's prisons. Desegregation should prompt a reappraisal of the goals and practices of our penal systems and the role of women in those systems.

A gender-neutral plan would make institutional assignments on the basis of factors currently recognized as determinative in the classification of male inmates: age, prior criminal history, psychological condition, educational and vocational needs. ${ }^{109}$ In integrated institutions, women would share the same jobs and classes, have the same privileges, and operate under the same rules as men with the same status. The mixing of men and women in the same cells would not be a feature of such a remedy, since the legitimate privacy and security interests would require separate cells for men and women. ${ }^{110}$ The structure of the prison and the degree of unrestricted movement permitted in the relevant housing unit would dictate whether men and women should be separated by room, hall, or cellblock. ${ }^{111}$

108. NewsweEk, supra note 10 , at 66 (citing less violence and forced homosexuality in cocorrectional prisons); Ruback, supra note 11, at 315-16.

109. The proposed system would probably concentrate women in lower security prisons, camps, and community correctional facilities. This would not, however, be based on a desire to protect them, but on the statistically low incidence of violent offenses by women. Chesney-Lind, supra note 6, at 197; Nagel \& Hagan, supra note 6, at 99-104.

110. All inmates, male and female, have certain legitimate expectations of privacy, even in prison. These include the opportunity to dress, bathe and perform eliminatory functions without observation by members of the opposite sex. The recognition of the equal protection rights of women in prison should lead to an increased awareness of the privacy rights of male prisoners. In recognition of these privacy interests, the American Correctional Association has promulgated Standard 2-4133, which provides for separate sleeping quarters within co-correctional institutions. AMERICAN CoRRECTIONAL ASS'N, STANDARdS FOR AdULT CORRECTIONAL INSTITUTIONS 34 (1981).

111. For example, in a cell-block design, where the interiors of the cells are visible to other inmates and guards, the cell-blocks would be designated as either male or female. In lower security prisons, however, which have separate rooms with solid or mostly solid doors, privacy would require only that each room be designated for male or female occupancy. 
In general, one would expect integrated prisons of different security levels to operate somewhat differently. Low security prisons could be patterned after the federal co-correctional institutions, but medium and maximum security prisons would require greater security measures and a more controlled environment, particularly during the period of transition from single-sex to integrated facilities. Internal security measures, especially staff-inmate ratios, would have to be increased while classification procedures are developed and implemented and inmates become reaccustomed to the mixed environment.

Sexual contact among inmates raises concerns that are problematic, but not insurmountable. Coerced sexual relations should be strictly and effectively prohibited in integrated institutions, as they should now be in single-sex prisons. Imposing celibacy on inmates, however, serves no correctional purpose, as the use of conjugal visits and furloughs demonstrates. Any such attempt is likely to prove futile. ${ }^{112}$

The small number of incarcerated women limits the extent to which desegregation is currently feasible. ${ }^{113}$ Unless integration is to be token, or to produce cruel and unusual conditions, ${ }^{114}$ some all-male prisons are inevitable. ${ }^{115}$

112. V. Fox, supra note 13 , at 218 . The disruption of marriages that might result if relationships involving married inmates were permitted has been raised as an objection to co-correctional prisons. Marital stability is an issue properly left to the determination of each inmate. If prisons want to assist married inmates, they could do so through more liberal provisions for conjugal visits, contact visits, and telephone calls, rather than barring all physical contact between members of the opposite sex, married or not.

Current restrictions in most prisons prevent women who give birth in prison from keeping the child; this policy, combined with the problems of care for pregnant inmates, see supra notes 84-86, provides strong disincentives to intentionally becoming pregnant in the hopes of securing some benefit. It is critical, however, that means of preventing unintentional pregnancies be readily available to men and women in integrated prisons. In this respect, officials in some co-correctional prisons are trapped: Having forbidden sexual activity, they must, in order to appear consistent, limit the availability of birth control to those eligible for furloughs or conjugal visits. Hence, they promote the likelihood of unwanted pregnancies among those inmates whose sexual activity is not acknowledged. Ruback, supra note 11 , at 319 .

113. See U.S. Nat'l Advisory Comm'n on Criminal Justice Standards and Goals, supra note 5 , at 379.

A co-correctional remedy would be counter-productive if it resulted in the isolation of individual women in otherwise all-male prisons, since rehabilitation and reintegration require meaningful interaction with members of both sexes. Because of the small number of women in prison, and the even smaller number of women classified as maximum security inmates, institutional assignments cannot be totally sex-blind. Of course, a gender-conscious remedy is permissible, following a determination of a constitutional violation. Fullilove v. Klutznick, 448 U.S. 448, 480-84 (1980); Swann v. CharlotteMecklenburg Bd. of Educ., 402 U.S. 1, 18-21 (1971).

114. Note, supra note 5 , at 1265.

115. The remedial nature of any desegregation plan, in combination with the small number of incarcerated women, has certain consequences for the rights of men in prison. It is not possible to provide all inmates, male and female, with an integrated environment. For example, women in the federal system constitute only $4.3 \%$ of the total inmate population. Two of the five prisons for women in that system are co-correctional. Thus, a relatively higher percentage of women are actually incarcerated in a co-correctional environment. By comparison, only a minute percentage of men in federal prisons are exposed to this environment. Bowker, supra note 10, at 235-36. The particular history of 


\section{GoNCLUSION}

The equal protection rights of women in prison have yet to be fully recognized. Unequal, segregated facilities continue not only to be tolerated, but to receive vindication through the parity of treatment standard now used to review sex-based disparities between male and female inmates. The reintegration function of corrections, the greater interests of the criminal justice system, and the rights of women in prison require more than parity of treatment. They demand wholesale structural reform: the implementation of a full desegregation plan. Only through shared facilities can women expect equal access to the prison services and rehabilitative programs currently available to men.

discrimination against women in general and women offenders in particular legitimates providing them with a full remedy, while their male counterparts have only an incomplete one.

A system could be set up to make co-correctional facilities available as incentives to men who comply with institutional rules and work actively toward their own rehabilitation. All men would have the opportunity to qualify for co-correctional placement, although this would not be realized in most cases. 